\title{
Phosphorus Fertilizers From Sewage Sludge Ash and Animal Blood Have No Effect on Earthworms
}

\author{
Magdalena Jastrzębska *D, Marta K. Kostrzewska and Kinga Treder \\ Department of Agroecosystems, Faculty of Environmental Management and Agriculture, University of Warmia \\ and Mazury in Olsztyn, Plac Łódzki 3, 10-718 Olsztyn, Poland; marta.kostrzewska@uwm.edu.pl (M.K.K.); \\ kinga.treder@uwm.edu.pl (K.T.) \\ * Correspondence: jama@uwm.edu.pl; Tel.: +48-89-523-4829
}

Received: 9 March 2020; Accepted: 5 April 2020; Published: 7 April 2020

\begin{abstract}
Soil invertebrates are crucial for agroecosystem functioning yet sensitive to agricultural practices, including fertilization. Considering the postulates of circular phosphorus economy, the use of fertilizers from secondary raw materials is likely to return and increase and may even become obligatory. The effects of recycled fertilizers on soil fauna communities, however, remain poorly understood. In this paper, the effect of phosphorus fertilizer $(\operatorname{Rec} F)$ and biofertilizer $(\operatorname{Rec} B)$ from sewage sludge ash and dried animal (porcine) blood on earthworm's occurrence in soil is discussed. RecB is RecF activated by phosphorus-solubilizing bacteria, Bacillus megaterium. Waste-based fertilizers were assessed in field experiments against commercial superphosphate and no $P$ fertilization. Three levels of $\mathrm{P}$ doses were established $\left(17.6,26.4\right.$, and $\left.35.2 \mathrm{~kg} \mathrm{P} \mathrm{ha}^{-1}\right)$. Earthworms were collected after the test crop harvest (spring or winter wheat). In the experiments two earthworm species, Aporrectodea caliginosa and Aporrectodea rosea, were identified. A large proportion of juvenile individuals were recorded in 2017. The recycled fertilizers used in the experiments used in recommended doses, similarly to superphosphate, did not alter the density, biomass, species composition, and structure of earthworms. Further long-term field research is recommended.
\end{abstract}

Keywords: Lumbricidae; Aporrectodea caliginosa; Aporrectodea rosea; phosphorus fertilizers; phosphorus-solubilizing microorganisms; renewable resources; heavy metals; Luvisols; wheat

\section{Introduction}

Earthworms (Lumbricidae) are listed among the most important soil-dwelling invertebrates [1]. They constitute a major component of soil fauna communities in most ecosystems [2]. The role of earthworms in soil fertility has been known for over a century [2]. So far, a great number of studies have been undertaken which highlight direct and indirect effects of their activity on biotic and abiotic soil properties, and, consequently, plant productivity. Due to their services, earthworms are referred to as ecosystem engineers $[3,4]$ and indicators of biological soil health $[5,6]$.

The occurrence, distribution, and abundance of earthworms can be affected by a range of environmental factors, including climate, soil conditions, food sources, metal concentration, and predator pressure [5]. In addition, in agroecosystems, agricultural practices such as irrigation, tillage, lime application, fertilizer and pesticide use, drainage, crop rotation, and cover crops influence earthworm abundance and activity [7] because they change one or more of the factors listed above $[5,8]$.

Despite potential soil pollution [9], increased use of inorganic fertilizers to enhance crop yields is a common practice in modern agriculture. Both beneficial and harmful effects of inorganic fertilizers on earthworm populations have been observed [10]. The positive effect is believed to be an indirect consequence of increased crop biomass production and the resulting increase in organic residues [11]. 
On the other hand, the toxic effects of inorganic fertilizers on earthworms, especially upon direct contact, have been reported [12,13].

Modern European agriculture faces a shortage of primary phosphorus (P) sources. Phosphate rock was included in the EU list of critical resources in 2014 [14]. A circular P economy, including recycling, seems to be a necessity in this part of the world. Inorganic and organic waste are often a source of nutrients in fertilizers $[15,16]$. As has been proved in numerous scientific centers, phosphate rocks can be replaced with P-rich secondary raw materials [17-19]. Municipal and industrial byproducts such as sewage sludge ash (SSA), animal bones, and blood may constitute the basis for alternative fertilizers [19]. An innovative approach, initiated to activate P from raw material, is the inclusion of phosphorus-solubilizing microbes (PSM) into waste-based preparations [20]. The use of recycled fertilizers is expected not only to provide satisfactory yields in terms of quantity $[21,22]$ and quality, but also not to cause negative changes in the soil environment. Concerning the latter, it should be taken into account that the introduction of nutrient carrier and PSM to the soil could alter soil properties both directly (nutrient content and availability, $\mathrm{pH}$, possible presence of toxic elements) and indirectly (e.g., through microbial activity modification or plant growth stimulation) [23]. Changes in habitat conditions could affect earthworm populations. It is also crucial to be aware that the consequences of recycled fertilizer use, while being invisible in the short term, may lead to significant environmental changes in the long term $[24,25]$.

The aim of this research has been to determine the impact of the fertilizers produced from SSA and animal blood on earthworm occurrence in the soil. The recycled fertilizer (RecF) and biofertilizer (RecB), i.e., RecF activated by Bacillus megaterium bacteria (PSM) were assessed against superphosphate, a commercial phosphorus fertilizer. It was hypothesized that the impact of the recycled fertilizers on soil earthworms would be similar or more favorable/less harmful than that of the traditional P fertilizer.

\section{Materials and Methods}

\subsection{Fertilizers}

In field experiments, the recycled P fertilizer (RecF) and biofertilizer (RecB) were compared to a commercial fertilizer superphosphate (SP). These preparations were manufactured from sewage sludge ash (ash from the incineration of sewage sludge biomass from wastewater treatment; SSA) and dried animal (porcine) blood. During RecB production, raw material (SSA + blood) was biologically activated by phosphorus-solubilizing bacteria, Bacillus megaterium. Both products were in the form of granules.

RecF and RecB were produced at the Institute of New Chemical Syntheses in Puławy (Poland), according to a concept developed at the Wrocław University of Science and Technology (Wrocław, Poland). The SSA originated from the Municipal Wastewater Treatment Plant 'Eyna' in Olsztyn (Poland), and dried blood was obtained from the meat processing industry. The bacteria strains were obtained from the Polish Collection of Microorganisms at the Institute of Immunology and Experimental Therapy of the Polish Academy of Sciences in Wrocław (Poland). The elemental composition of the recycled fertilizers is presented in Table 1. The production process was described by Rolewicz et al. [26]. 
Table 1. Elemental composition of the recycled fertilizers.

\begin{tabular}{cccccc}
\hline \multirow{2}{*}{ Element } & \multirow{2}{*}{ Unit } & \multicolumn{2}{c}{$\mathbf{2 0 1 6}$} & \multicolumn{2}{c}{$\mathbf{2 0 1 7}$} \\
\cline { 3 - 6 } & & RecF & RecB & RecF & RecB \\
\hline $\mathrm{P}$ & & 8.68 & 9.55 & 5.40 & 4.95 \\
$\mathrm{~N}$ & & 2.89 & 2.87 & 3.44 & 3.15 \\
$\mathrm{~K}$ & & 1.09 & 1.16 & 0.62 & 0.67 \\
$\mathrm{C}$ & \% mass. & 13.4 & 14.6 & 14.2 & 12.3 \\
$\mathrm{Mg}$ & & 1.54 & 1.70 & 0.79 & 0.78 \\
$\mathrm{~S}$ & & 0.56 & 0.56 & 0.47 & 0.40 \\
$\mathrm{C}$ & & 12.5 & 13.9 & 16.5 & 18.1 \\
\hline $\mathrm{Fe}$ & & 26.9 & 29.0 & 11.4 & 11.3 \\
$\mathrm{Al}$ & \multirow{2}{*}{$\mathrm{g} \mathrm{kg}^{-1}$} & 23.7 & 25.5 & 11.3 & 12.1 \\
$\mathrm{Zn}$ & & 3.14 & 3.29 & 1.09 & 0.99 \\
\hline $\mathrm{As}$ & & 31.4 & 20.0 & 15.5 & 20.5 \\
$\mathrm{Cd}$ & & $<0.01$ & 0.345 & 0.660 & 0.742 \\
$\mathrm{Cr}$ & & 54.7 & 62.9 & 63.9 & 59.1 \\
$\mathrm{Cu}$ & & 778 & 850 & 334 & 334 \\
$\mathrm{Ni}$ & & 54.8 & 62.6 & 28.5 & 21.2 \\
$\mathrm{~Pb}$ & $\mathrm{mg} \mathrm{kg}^{-1}$ & 19.9 & 21.8 & 0.920 & 4.53 \\
$\mathrm{~B}$ & & 71.3 & 74.1 & 41.1 & 57.6 \\
$\mathrm{Ba}$ & & 349 & 382 & 162 & 168 \\
$\mathrm{Co}$ & & 14.0 & 16.2 & 5.24 & 4.24 \\
$\mathrm{Mn}$ & & 562 & 609 & 299 & 437 \\
$\mathrm{Mo}$ & & 35.3 & 23.7 & 9.25 & 13.9 \\
\hline $\mathrm{Dn}$ & & &
\end{tabular}

According to the Department of Advanced Material Technologies of the Wrocław University of Science and Technology (Wrocław, Poland).

Superphosphate Fosdar ${ }^{\mathrm{TM}} 40$ (Gdańsk Phosphorus Fertilizer Plant 'Fosfory' Sp. z o.o., Gdańsk, Poland) was purchased on the market. This P fertilizer contains $17.6 \% \mathrm{P}, 7.15 \% \mathrm{Ca}, 2.00 \% \mathrm{~S}$, and microelements $(\mathrm{B}, \mathrm{Co}, \mathrm{Cu}, \mathrm{Fe}, \mathrm{Mn}, \mathrm{Mo}$, and $\mathrm{Zn})$, according to the commercial information provided on the label.

\subsection{Soil and Meteorological Conditions}

Three field experiments with spring $(2016,2017)$ or winter $(2017$; sown in autumn 2016) common wheat (Triticum aestivum ssp. vulgare MacKey) were conducted. In each experiment, the soil on which wheat was grown met the requirements of the species (Table 2) and was within the range of soils preferred by earthworms [27].

Table 2. Soil characteristics before the start of the experiments.

\begin{tabular}{|c|c|c|c|c|c|c|c|c|}
\hline \multirow{2}{*}{ Experiment } & \multirow{2}{*}{ Soil Type } & \multirow{2}{*}{ Soil Texture } & \multirow{2}{*}{$\begin{array}{c}\mathrm{pH} \text { in } \\
\mathrm{KCl}\end{array}$} & \multicolumn{5}{|c|}{ Total, $\mathrm{g} \mathrm{kg}^{-1}$} \\
\hline & & & & $\mathrm{C}$ & $\mathbf{N}$ & $\mathbf{P}$ & $\mathbf{K}$ & $\mathrm{Mg}$ \\
\hline Spring wheat 2016 & Luvisols $^{1}$ & $\begin{array}{l}\text { sandy clay } \\
\text { loam }\end{array}$ & 6.28 & 8.53 & 1.42 & 0.61 & 2.98 & 2.02 \\
\hline Spring wheat 2017 & Luvisols & $\begin{array}{l}\text { sandy clay } \\
\text { loam }\end{array}$ & 6.23 & 8.48 & 1.34 & 0.60 & 3.14 & 1.94 \\
\hline Winter wheat 2017 & Luvisols & sandy loam & 4.98 & 6.48 & 1.01 & 0.49 & 2.95 & 1.88 \\
\hline
\end{tabular}

Meteorological conditions in the period of one month before earthworm sampling are presented in Table 3. In both growing seasons, fairly heavy rainfall and moderate temperatures in July and early August could have stimulated earthworm activity at the time of earthworm sampling [29,30]. 
Table 3. Atmospheric precipitation and air temperature during the study period according to the Meteorological Station in Bałcyny, Poland.

\begin{tabular}{|c|c|c|c|c|c|c|c|c|c|}
\hline \multirow{3}{*}{ Year } & \multirow{3}{*}{ Month } & \multicolumn{4}{|c|}{ Atmospheric Precipitation (mm) } & \multicolumn{4}{|c|}{ Air Temperature $\left({ }^{\circ} \mathrm{C}\right)$} \\
\hline & & \multicolumn{3}{|c|}{ Period of Ten Days } & \multirow{2}{*}{ Total } & \multicolumn{3}{|c|}{ Period of Ten Days } & \multirow{2}{*}{ Average } \\
\hline & & 1st & 2nd & 3rd & & 1st & 2nd & 3rd & \\
\hline \multirow{2}{*}{2016} & July & 39.6 & 34.0 & 65.0 & 138.6 & 17.5 & 18.1 & 19.9 & 18.5 \\
\hline & August & 54.5 & 10.4 & 7.0 & 71.9 & 17.7 & 15.6 & 19.3 & 17.6 \\
\hline \multirow{2}{*}{2017} & July & 29.4 & 20.7 & 56.0 & 106.1 & 16.0 & 17.2 & 18.5 & 17.3 \\
\hline & August & 31.6 & 11.7 & 11.5 & 54.8 & 20.8 & 19.2 & 16.3 & 18.7 \\
\hline
\end{tabular}

\subsection{Experimental Design and Agronomic Management}

In the field experiments, RecF and RecB were assessed against SP and no phosphorus (No P) treatments. In addition, three different P levels were established: (1) 17.6 , (2) 26.4 , and (3) $35.2 \mathrm{~kg} \mathrm{P}$ $\mathrm{ha}^{-1}$; therefore, finally, ten treatments of P fertilization were compared (Table 4).

Table 4. Fertilization treatments compared in the experiments.

\begin{tabular}{|c|c|c|}
\hline Treatment Symbol & Fertilizer & $\mathrm{P}$ Dose, $\mathrm{kg} \mathrm{P}$ ha $^{-1}$ \\
\hline No $P$ & without phosphorus fertilizer & 0 \\
\hline $\mathrm{SP}_{1}$ & superphosphate & 17.6 \\
\hline $\mathrm{SP}_{2}$ & & 26.4 \\
\hline $\mathrm{SP}_{3}$ & & 35.2 \\
\hline $\operatorname{RecF}_{1}$ & fertilizer from sewage sludge ash and & 17.6 \\
\hline $\operatorname{RecF}_{2}$ & dried animal blood & 26.4 \\
\hline $\mathrm{RecF}_{3}$ & & 35.2 \\
\hline $\operatorname{RecB}_{1}$ & biofertilizer from sewage sludge ash & 17.6 \\
\hline $\operatorname{RecB}_{2}$ & and dried animal blood & 26.4 \\
\hline $\operatorname{RecB}_{3}$ & & 35.2 \\
\hline
\end{tabular}

Phosphorus fertilizers were applied before the sowing of wheat. They were manually scattered on the soil surface and then mixed with the soil by harrowing. Other basic agrotechnical data for the experiments are presented in Table 5.

Table 5. Basic agricultural data for the experiments.

\begin{tabular}{|c|c|c|c|}
\hline \multirow{2}{*}{ Item } & \multicolumn{3}{|c|}{ Experiment } \\
\hline & Spring Wheat 2016 & Spring Wheat 2017 & Winter Wheat 2017 \\
\hline Wheatcultivar & Monsun & Monsun & Julius \\
\hline Previous crop & winter rape & spring wheat & winter wheat \\
\hline Soil tillagesystem & plough tillage & plough tillage & plough tillage \\
\hline Fertilization & & & \\
\hline$-\mathrm{K}_{2} \mathrm{O}^{1}, \mathrm{~kg} \mathrm{ha}^{-1}$ & 100 & 100 & 100 \\
\hline$-\mathrm{N}^{2}, \mathrm{~kg} \mathrm{ha}^{-1}$ & 130 & 110 & 150 \\
\hline \multicolumn{4}{|l|}{ Plantprotection } \\
\hline -Herbicides & florasulam + 2,4-D (29 May) & florasulam + 2,4-D (22 May) & florasulam + 2,4-D (13 May) \\
\hline -Fungicides & $\begin{array}{l}\text { thiophanate-methyl } \\
\text { +tetraconazole ( } 9 \\
\text { June)azoxystrobin ( } 8 \text { July) }\end{array}$ & $\begin{array}{l}\text { thiophanate-methyl }+ \\
\text { tetraconazole (6 June) } \\
\text { azoxystrobin + (propiconazole + } \\
\text { cyproconazole) (28 June) }\end{array}$ & $\begin{array}{c}\text { fenpropimorph }+ \text { epoxiconazole }+ \\
\text { metrafenone }(16 \text { May)fluxapyroxad }+ \\
\text { pyraclostrobin + epoxiconazole } \\
\text { (8 June) }\end{array}$ \\
\hline -Insecticides & lambda-cyhalothrin(6 June) & deltamethrin (6 June) & deltamethrin (6 June) \\
\hline -Growthregulators & - & - & trinexapac-ethyl (16 May) \\
\hline Sowing date & 21 April 2016 & 20 April 2017 & 4 October 2016 \\
\hline Harvest date & 12 August 2016 & 18 August 2017 & 4 August 2017 \\
\hline
\end{tabular}

Experiments were established in a randomized block design. In each experiment, particular experimental treatments were performed in four replications (plots) (Figure S1). The area of a single experimental plot was $20 \mathrm{~m}^{2}$. 


\subsection{Earthworm Sampling and Identification}

Earthworms were harvested mechanically 2-3 days after the wheat harvest. Soil columns with a surface area of $0.0625 \mathrm{~m}^{2}(0.25 \mathrm{~m} \times 0.25 \mathrm{~m})$ and a depth of $0.4 \mathrm{~m}$ were dug out of each plot, then crushed and passed through a sieve, and individuals of Lumbricidae were collected. Afterwards, the earthworms were transported to the laboratory, where they were washed, counted, and weighed. Anaesthetized in a 30\% ethanol (Czempur, Piekary Śląkie, Poland) solution, earthworms were preserved in a $\%$ formalin (Czempur, Piekary Ślaskie, Poland) and 75\% ethanol solution for the subsequent analysis of the species composition. The earthworms were sorted into adults and juvenile forms. The adult individuals were further classified into species using an identification key to soil-dwelling oligochaetes [31]. The species composition, number and biomass of earthworms in the $0-0.4 \mathrm{~m}$ soil layer were expressed per $1 \mathrm{~m}^{2}$ of plot area.

\subsection{Statistical Analysis}

The normality of variable distribution was checked using the Shapiro-Wilk W-test, and the homogeneity of variance was checked using Levene's test. Since the assumptions of the analysis of variance were not met, the results were processed by the alternative nonparametric Kruskal-Wallis test. The calculations were performed using Statistica 12.0 software [32].

\section{Results and Discussion}

Both in 2016 and 2017, thermal and rain conditions in July and early August promoted earthworm presence in the 0-0.4 m soil layer. Having found convenient habitat moisture at this level of the soil profile, the individuals of Lumbricidae did not enter into diapause or migrate deeper into the soil seeking better conditions [30]. The density of earthworms found in the studied soil columns ranged from 6 to 44 individuals and the biomass from 1.1 to $21.5 \mathrm{~g}$ per $\mathrm{m}^{2}$ (Table 6). These values are similar to those presented by Tiwari [33] from a sandy loam Oxisol in India, but smaller than the values reported by other authors from different arable soils in Poland [4] and Slovakia [34]. The abovementioned differences may have been caused by different timing of sampling, which did not correspond to the periods of the highest earthworm activity (spring and autumn) indicated in the literature [4,34]. In 2016, the average earthworm biomass was relatively higher than in 2017 due to a greater share of adult individuals in the community.

Table 6. Earthworm density (no. $\mathrm{m}^{-2}$ ) and biomass $\left(\mathrm{g} \mathrm{m}^{-2}\right)$ in the $0-0.4 \mathrm{~m}$ layer of soil under wheat (averages from four replications/plots).

\begin{tabular}{|c|c|c|c|c|c|c|}
\hline \multirow{3}{*}{$P$ Treatment } & \multicolumn{2}{|c|}{ Spring Wheat 2016} & \multicolumn{2}{|c|}{ Spring Wheat 2017} & \multicolumn{2}{|c|}{ Winter Wheat 2017} \\
\hline & \multicolumn{6}{|c|}{ Earthworm } \\
\hline & Density & Biomass & Density & Biomass & Density & Biomass \\
\hline No P & 22 & 16.3 & 18 & 7.8 & 6 & 1.1 \\
\hline $\mathrm{SP}_{1}$ & 18 & 9.8 & 24 & 5.4 & 22 & 7.6 \\
\hline $\mathrm{SP}_{2}$ & 26 & 21.5 & 32 & 12.0 & 12 & 7.3 \\
\hline $\mathrm{SP}_{3}$ & 18 & 9.4 & 20 & 8.0 & 16 & 8.5 \\
\hline $\operatorname{RecF}_{1}$ & 26 & 15.0 & 12 & 3.2 & 20 & 8.1 \\
\hline $\mathrm{RecF}_{2}$ & 8 & 6.7 & 16 & 3.5 & 20 & 11.0 \\
\hline $\mathrm{RecF}_{3}$ & 12 & 6.1 & 12 & 3.6 & 12 & 6.6 \\
\hline $\operatorname{RecB}_{1}$ & 14 & 11.4 & 16 & 6.7 & 10 & 3.8 \\
\hline $\operatorname{RecB}_{2}$ & 16 & 9.1 & 6 & 1.6 & 14 & 8.0 \\
\hline $\operatorname{RecB}_{3}$ & 28 & 16.4 & 44 & 11.2 & 8 & 4.9 \\
\hline
\end{tabular}

No significant differences between treatments according to the Kruskal-Wallis test at $p \leq 0.05$.

In all experiments, only two earthworm species were identified, i.e., Aporrectodea caliginosa and Aporrectodea rosea (Figure 1), which is hardly surprising. These species are among the most common in Poland [31] and Europe [35], and they were the only ones recorded by Kanianska et al. [34] in some study sites in Slovakia. In 2016, mainly adult earthworms were noted, and on average, A. caliginosa and 
A. rosea occurred in similar proportions (42\% and 39\%, respectively). In 2017, among the earthworm individuals found after spring wheat harvest, juvenile forms dominated, often constituting $100 \%$ of the community. Adults were found sporadically. A large proportion of juvenile forms (mostly over $50 \%$ ) were also recorded in the soil after the winter wheat harvest. In this experiment, A. rosea was predominant. A high number of juvenile individuals is often thought to be an indicator of suitable conditions for earthworm development $[29,36]$. A dominance of juvenile forms over adult earthworms has also been noticed by other authors [4,34].

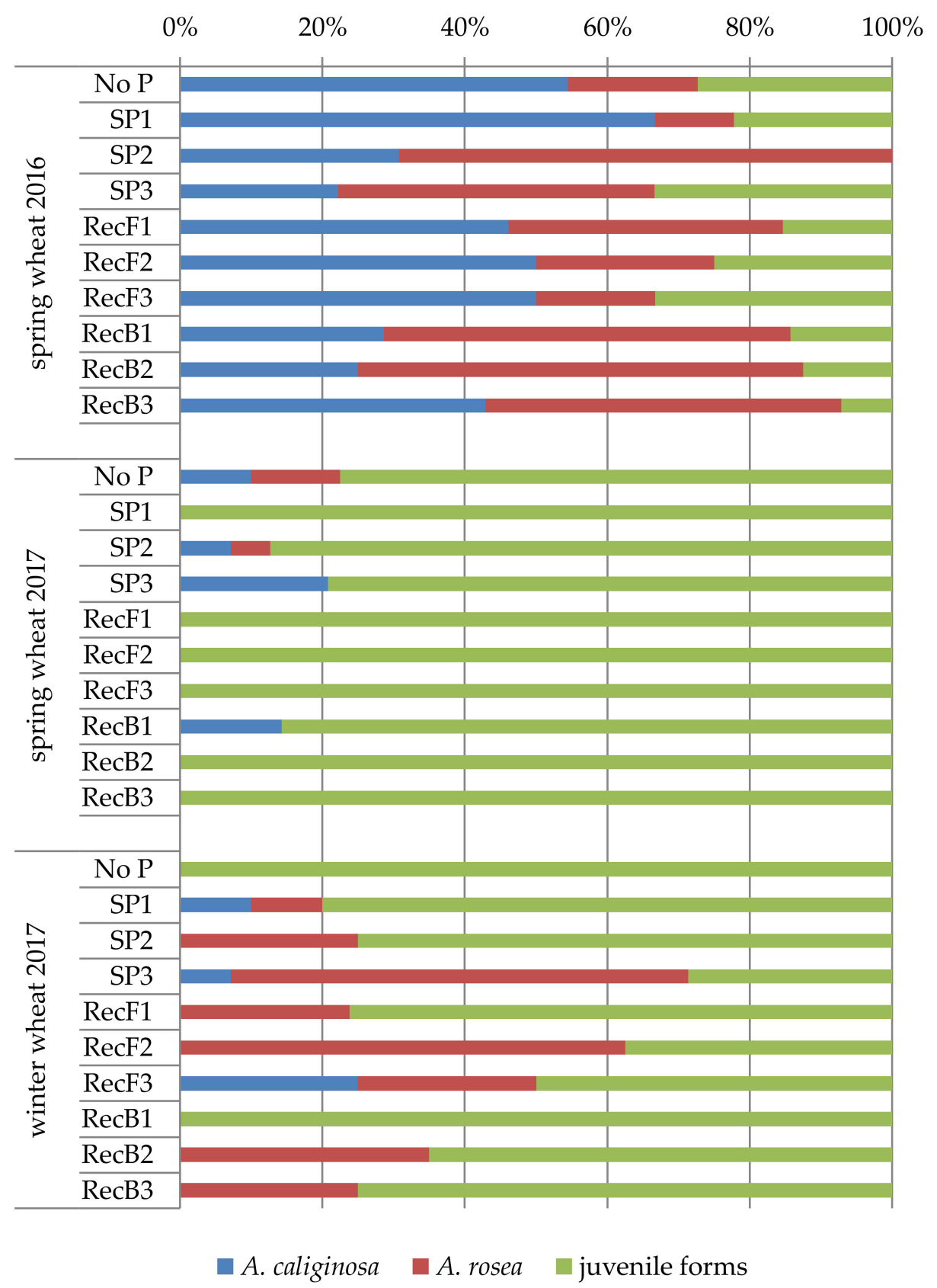

Figure 1. Species composition and structure of earthworms (based on the density of individuals). No significant differences between treatments according to the Kruskal-Wallis test at $p \leq 0.05$.

In none of the conducted experiments did the earthworm density and biomass depend on the type of $\mathrm{P}$ fertilizers used or their doses (Table 6). Moreover, earthworm abundance (density and biomass) under no $\mathrm{P}$ treatment did not differ from that under fertilizers. In addition, no evident link between 
the species composition and structure of earthworms and the applied P fertilization was observed (Figure 1).

To compare, in the study by Tiwari [33] conducted in an Oxisol (India), the single superphosphate applied at $\mathrm{P}$ dose of $25 \mathrm{~kg} \mathrm{ha}^{-1}$ did not change the earthworm density and biomass in comparison to control treatment (no fertilizer). An increase in the number and biomass of earthworms with the addition of superphosphate to pastures in Australia and New Zealand was reported [37]; however, the authors argued that $\mathrm{P}$ fertilizer led to an increase in plant production in these ecosystems and, hence, available food. In contrast, in other studies [34,38,39], a negative relationship between earthworm biomass and $\mathrm{P}$ content in soil was found. Some authors proved that inorganic fertilizers, including superphosphate, can be toxic to earthworms upon direct contact $[12,13]$.

In the current study, the SSA is the main raw material for the fertilizers produced, and one that may raise concerns about the heavy metal presence [18]. The issue of toxic element occurrence is key since Khan et al. [40], based on a pot experiment, claimed that the high content of heavy metals in the tested fiber and chemical industry sludge ashes was the reason for the decrease in the number of adults, juveniles, cocoons, and fresh weight of the earthworm Pheretima posthuma found four months after the waste application. Using animal blood as a fertilizer for organic farming [41,42] and a fertilizer binder [43] was recommended. The content of potentially toxic elements in fertilizers tested in the current study was low (Table 1), and the fertilizer doses used were not excessive. According to other research, metals such as copper $(\mathrm{Cu})$, zinc $(\mathrm{Zn})$, and iron $(\mathrm{Fe})$, which are contained in RecF and RecB fertilizers, may also be toxic to earthworms $[13,44,45]$, although they play the role of microelements for plants. Neuhauser et al. [44] proved that $\mathrm{Cu}$ and $\mathrm{Zn}$ were more toxic to Eisenia fetida than cadmium (Cd) and lead $(\mathrm{Pb})$. Toxicity of aluminum $(\mathrm{Al})$ to earthworms was reported as well [46]. Additional reflections (and caution) should also be prompted by studies on long-term use of sewage sludge documenting the negative impact of metal accumulation in the soil on soil microorganisms [24,25,47].

To date, only a few studies have examined the effect of SSA-based fertilizers on earthworms. Rastetter et al. [48] ecotoxicologically analyzed three crystallization products and five ash products of recovered phosphate-containing materials, obtained from treated sewage sludge, sludge liquors or sludge ashes from municipal wastewater treatment plants in Europe. The phosphate recyclates were compared with a conventional phosphate fertilizer (triple superphosphate). The avoidance test with the earthworm Eisenia fetida was used to determine the effects of chemicals on behavior of earthworms. The authors concluded that relevant agronomical application amounts of all phosphate recyclates and triple superphosphate might not have an acute toxic effect on the soil invertebrates. In contrast to endogeic species found in the current study, E. fetida is epigeic, and some research has suggested that the sensitivity of ecologically different earthworm species to chemicals/pollutants may vary $[49,50]$. The earlier field studies by Jastrzębska et al. [23,51-53] showed that suspension and granular fertilizers from SSA and/or animal bones with a low content of toxic elements and applied in recommended doses did not alter the abundance (density and biomass), species composition, and structure of soil earthworms. In the cited studies, only endogeic species were found, both in fertilized and nonfertilized soil. The current study is in line with the above results. It is also worth highlighting that the peculiar impact of PSM included in biofertilizer on earthworms was not noticed. The same results were obtained by Jastrzębska et al. [53] when fertilizer and biofertilizer from SSA and animal bones were compared. It can thus be concluded that PSM introduced into the soil in the amounts required for biofertilizers do not significantly alter the earthworm habitat conditions.

In the presented experiments, chemical plant protection was used. This may create the assumption that pesticides affected earthworms and masked the effects of fertilizers. However, in the earlier study with SSA-based suspension fertilizer, Jastrzębska et al. [23] did not observe the effect of pesticides (applied at recommended doses) on earthworms, nor the interaction between phosphorus fertilizations and plant protection (no plant protection vs. chemical plant protection). Considering the abovementioned results, we believe that this phenomenon did not occur in the presented study either. 


\section{Conclusions}

Recycled fertilizers produced from secondary raw materials, such as sewage sludge ash with a low content of toxic elements and dried animal blood, applied in reasonable doses, similarly to superphosphate, did not pose a threat to earthworms. The impact on these organisms is not a limitation to their use. However, taking into account the potential toxicity of waste, relevant studies preceding the recommendation of each new recyclate-based product and long-term field ones are postulated.

Supplementary Materials: The following are available online at http://www.mdpi.com/2073-4395/10/4/525/s1, Figure S1: Scheme of experimental design.

Author Contributions: Conceptualization, M.J.; methodology, M.J., M.K.K., and K.T.; formal analysis, M.J.; investigation, K.T., M.J., and M.K.K.; resources, M.J. and K.T.; data curation, M.J.; writing-original draft preparation, M.J.; writing—review and editing, M.K.K.; visualization, M.J.; funding acquisition, M.J., M.K.K., and K.T. All authors have read and agreed to the published version of the manuscript.

Funding: This research was funded by the National Centre for Research and Development, Poland, grant number PBS 2/A1/11/2013.

Acknowledgments: The Institute of New Chemical Synthesis in Puławy is highly acknowledged for providing fertilizers for field experiments and Agnieszka Saeid from the Wrocław University of Science and Technology for the information on the fertilizers' chemical composition.

Conflicts of Interest: The authors declare no conflict of interest.

\section{References}

1. Van Groenigen, J.W.; Lubbers, I.M.; Vos, H.M.J.; Brown, G.G.; De Deyn, G.B.; Van Groenigen, K.J. Earthworms increase plant production: A meta-analysis. Sci. Rep. 2014, 4, 6365. [CrossRef] [PubMed]

2. Bhadauria, T.; Saxena, K.G. Role of earthworms in soil fertility maintenance through the production of biogenic structures. Appl. Environ. Soil Sci. 2010, 2010. [CrossRef]

3. Johnston, A.S.A.; Sibly, R.M.; Hodson, M.E.; Alvarez, T.; Thorbek, P. Effects of agricultural management practices on earthworm populations and crop yield: Validation and application of a mechanistic modelling approach. J. Appl. Ecol. 2015, 52, 1334-1342. [CrossRef]

4. Feledyn-Szewczyk, B.; Radzikowski, P.; Stalenga, J.; Matyka, M. Comparison of the effect of perennial energy crops and arable crops on earthworm populations. Agronomy 2019, 9, 675. [CrossRef]

5. Ashworth, A.J.; Allen, F.L.; Tyler, D.D.; Pote, D.H.; Shipitalo, M.J. Earthworm populations are affected from long-term crop sequences and bio-Covers under no-Tillage. Pedobiologia 2017, 60, 27-33. [CrossRef]

6. Doran, J.W.; Zeiss, M.R. Soil health and sustainability: Managing the biotic component of soil quality. Appl. Soil Ecol. 2000, 15, 3-11. [CrossRef]

7. Edwards, C.A.; Bohlen, P.J. Biology and Ecology of Earthworms, 3rd ed.; Chapman \& Hall: London, UK, $1996 ;$ p. 426.

8. Baldivieso-Freitas, P.; Blanco-Moreno, J.M.; Gutiérrez-López, M.; Peigné, J.; Pérez-Ferrer, A.; Trigo-Aza, D.; Sans, F.X. Earthworm abundance response to conservation agriculture practices in organic arable farming under Mediterranean climate. Pedobiologia 2018, 66, 58-64. [CrossRef]

9. Radziemska, M.; Bęś, A.; Gusiatin, Z.M.; Majewski, G.; Mazur, Z.; Bilgin, A.; Jaskulska, I.; Brtnický, M. Immobilization of Potentially Toxic Elements (PTE) by Mineral-Based Amendments: Remediation of Contaminated Soils in Post-Industrial Sites. Minerals 2020, 10, 87. [CrossRef]

10. Lalthanzara, H.; Ramanujam, S.N. Effect of fertilizer (NPK) on earthworm population in the agro-Forestry system of Mizoram India. Sci. Vis. 2010, 10, 159-167.

11. Marhan, S.; Scheu, S. The influence of mineral and organic fertilisers on the growth of the endogeic earthworm Octolasion tyrtaeum (Savigny). Pedobiologia 2005, 49, 239-249. [CrossRef]

12. Abbiramy, K.S.K.; Ross, P.R.; Paramanandham, J.P. Assessment of acute toxicity of superphosphate to Eisenia foetida using paper contact method. Asian J. Plant Sci. Res. 2013, 3, 112-115.

13. Shruthi, N.; Biradar, A.P.; Muzammil, S. Toxic effect of inorganic fertilizers to earthworms (Eudrilus eugeniae). J. Entomol. Zool. Stud. 2017, 5, 1135-1137.

14. European Commission. Report on critical raw materials for the EU. In Report of the Ad-Hoc Working Group on Defining Critical Raw Materials; EC: Brussels, Belgium, 2014; p. 41. 
15. Romiński, M.; Michalak, P.; Jaskulski, D.; Jaskulska, I. Technology for manufacturing granulated magnesium fertilizers with the use of wastes from chlorine production. Przem. Chem. 2011, 90, 628-630.

16. Jaskulski, D.; Jaskulska, I. Possibility of using waste from the polyvinyl chloride production process for plant fertilization. Pol. J. Environ. Stud. 2011, 20, 351-354.

17. Smol, M. The importance of sustainable phosphorus management in the circular economy (CE) model: The Polish case study. J. Mater. Cycl. Waste Manag. 2019, 21, 227-238. [CrossRef]

18. Herzel, H.; Krüger, O.; Hermann, L.; Adam, C. Sewage sludge ash-A promising secondary phosphorus source for fertilizer production. Sci. Total Environ. 2016, 542, 1136-1143. [CrossRef]

19. Saeid, A.; Wyciszkiewicz, M.; Jastrzębska, M.; Chojnacka, K.; Górecki, H. A concept of production of new generation of phosphorus-Containing biofertilizers. BioFertP project. Przem. Chem. 2015, 94, 361-365.

20. Saeid, A.; Labuda, M.; Chojnacka, K.; Górecki, H. Use of microorganism in production of phosphorus fertilizers. Przem. Chem. 2012, 91, 956-958.

21. Jastrzębska, M.; Kostrzewska, M.K.; Saeid, A.; Treder, K.; Makowski, P.; Jastrzebski, W.P.; Okorski, A. Granulated phosphorus fertilizer made of ash from biomass combustion and bones with addition of Bacillus megaterium in the field assessment. Part 1. Impact on yielding and sanitary condition of winter wheat. Przem. Chem. 2017, 96, 2168-2174.

22. Severin, M.; Breuer, J.; Rex, M.; Stemann, J.; Adam, C.; Van den Weghe, H.; Kücke, M. Phosphate fertilizer value of heat treated sewage sludge ash. Plant Soil Environ. 2014, 60, 555-561. [CrossRef]

23. Jastrzębska, M.; Kostrzewska, M.K. Using an environment-friendly fertiliser from sewage sludge ash with the addition of Bacillus megaterium. Minerals 2019, 9, 423. [CrossRef]

24. McGrath, S.P.; Chaudri, A.M.; Giller, K.E. Long-term effects of metals in sewage sludge on soils, microorganisms and plants. J. Ind. Microbiol. 1995, 14, 94-104. [CrossRef] [PubMed]

25. Charlton, A.; Sakrabani, R.; Tyrrel, S.; Rivas Casado, M.; McGrath, S.P.; Crooks, B.; Cooper, P.; Campbell, C.D. Long-term impact of sewage sludge application on soil microbial biomass: An evaluation using meta-analysis. Environ. Pollut. 2016, 219, 1021-1035. [CrossRef] [PubMed]

26. Rolewicz, M.; Rusek, P.; Borowik, K. Obtaining of granular fertilizers based on ashes from combustion of waste residues and ground bones using phosphorous solubilization by bacteria Bacillus megaterium. J. Environ. Manag. 2018, 216, 128-132. [CrossRef]

27. Pfiffner, L. Earthworms-architects of fertile soils. Their significance and recommendations for their promotion in agriculture. In Technical Guide on Earthworms; Research Institute of Organic Agriculture: Frick, Switzerland, 2014.

28. Food and Agriculture Organization of the United Nations. World reference base for soil resources 2014. In International Soil Classification System for Naming Soils and Creating Legends for Soil Maps; Food and Agriculture Organization of the United Nations: Rome, Italy, 2014.

29. Ivask, M.; Kuu, A.; Truu, M.; Truu, J. The effect of soil type and soil moisture on earthworm communities. Agric. Sci. 2006, 17, 7-11.

30. Singh, J.; Schädler, M.; Demetrio, W.; Brown, G.G.; Eisenhauer, N. Climate change effects on earthworms-A review. Soil Org. 2019, 91, 114.

31. Kasprzak, K. Soil Oligochaeta. 3. Family: Earthworms (Lumbricidae); Państwowe Wydawnictwo Naukowe: Warsaw, Poland, 1986; p. 186.

32. Statistica (Data Analysis Software System), version 12; StatSoft: Tulsa, OK, USA, 2014.

33. Tiwari, S.C. Effects of organic manure and NPK fertilization on earthworm activity in an Oxisol. Biol. Fertil. Soil 1993, 16, 293-295. [CrossRef]

34. Kanianska, R.; Jad'ud'ová, J.; Makovníková, J.; Kizeková, M. Assessment of relationships between earthworms and soil abiotic and biotic factors as a tool in sustainable agricultural. Sustainability 2016, 8, 906. [CrossRef]

35. Dinter, A.; Oberwalder, C.; Kabouw, P.; Coulson, M.; Ernst, G.; Leicher, T.; Miles, M.; Weyman, G.; Klein, O. Occurrence and distribution of earthworms in agricultural landscapes across Europe with regard to testing for responses to plant protection products. J. Soil Sedim. 2013, 13, 278-293. [CrossRef]

36. Geraskina, A.P. Restoration of earthworms community (Oligochaeta: Lumbricidae) at sand quarries (Smolensk Oblast, Russia). Ecol. Quest. 2019, 30, 1-13. [CrossRef]

37. Tripathi, G.; Kachhwaha, N.; Dabi, I.; Singh, J. Earthworms as bioengineers. In Frontiers in Ecology Research; Nova Publishers: New York, NY, USA, 2007; p. 227. 
38. Iordache, M.; Borza, I. Relation between chemical indices of soil and earthworm abundance under chemical fertilization. Plant Soil Environ. 2010, 56, 401-407. [CrossRef]

39. Chauhan, R.P.; Pande, K.R.; Shah, S.C.; Dhakal, D.D. Soil properties and earthworm dynamics affected by land use systems in western Chitwan, Nepal. J. Inst. Agric. Anim. Sci. 2015, 33-34, 123-128. [CrossRef]

40. Khan, M.U.; Ahmed, M.; Nazim, K. The population behavior of earth worm (Oheritema posthuma Kinberg) under the influence of industrial waste. FUUAST J. Biol. 2017, 7, 1-8.

41. Jayathilakan, K.; Sultana, K.; Radhakrishna, K.; Bawa, A.S. Utilization of byproducts and waste materials from meat, poultry and fish processing industries: A review. J. Food Sci. Tech. 2012, 49, 278-293. [CrossRef] [PubMed]

42. Yunta, F.; Di Foggia, M.; Bellido-Díaz, V.; Morales-Calderón, M.; Tessarin, P.; López-Rayo, S.; Tinti, A.; Kovács, K.; Klencsár, Z.; Fodor, F.; et al. Blood meal-based compound. Good choice as iron fertilizer for organic farming. J. Agric. Food Chem. 2013, 61, 3995-4003. [CrossRef] [PubMed]

43. Kowalski, Z.; Makara, A.; Banach, M. Krew zwierzęca, metody jej przetwarzania i zastosowanie. Tech. Trans. Chem. 2011, 108, 87-105.

44. Neuhauser, E.F.; Loehr, R.C.; Milligan, D.L.; Malecki, M.R. Toxicity of metals to the earthworm Eisenia fetida. Biol. Fert. Soil 1985, 1, 149-152. [CrossRef]

45. Spurgeon, D.J.; Hopkin, S.P. The effects of metal contamination on earthworm populations around a smelting works: Quantifying species effects. Appl. Soil Ecol. 1996, 4, 147-160. [CrossRef]

46. Zhao, L.; Qiu, J.P. Aluminum bioaccumulation in the earthworm and acute toxicity to the earthworm. In Proceedings of the 4th International Conference on Bioinformatics and Biomedical Engineering, Chengdu, China, 18-20 June 2010.

47. Stoven, K.; Schnug, E. Long term effects of heavy metal enriched sewage sludge disposal in agriculture on soil biota. Landbauforsch. Volkenrode 2009, 59, 131-138.

48. Rastetter, N.; Rothhaupt, K.O.; Gerhardt, A. Ecotoxicological Assessment of Phosphate Recyclates from Sewage Sludges. Water Air Soil Pollut. 2017, 228, 171. [CrossRef]

49. Elyamine, A.M.; Afzal, J.; Rana, M.S.; Imran, M.; Cai, M.; Hu, C. Phenanthrene mitigates cadmium toxicity in earthworms Eisenia fetida (epigeic specie) and Aporrectodea caliginosa (endogeic specie) in soil. Int. J. Environ. Res. Public Health 2018, 15, 2384. [CrossRef] [PubMed]

50. Yahyaabadi, M.; Hamidian, A.H.; Ashrafi, S. Dynamics of earthworm species at different depths of orchard soil receiving organic or chemical fertilizer amendments. Eurasian J. Soil Sci. 2018, 7, 318-325. [CrossRef]

51. Jastrzębska, M.; Kostrzewska, M.K.; Makowski, P.; Treder, K.; Marks, M. Effects of ash and bone phosphorus biofertilizers on Bacillus megaterium counts and select biological and physical soil properties. Pol. J. Environ. Stud. 2015, 24, 1603-1609. [CrossRef]

52. Jastrzębska, M.; Kostrzewska, M.K.; Makowski, P.; Treder, K.; Jastrzębski, W.P. Functional properties of granulated ash and bone-based phosphorus biofertilizers in the field assessment. Part 3. Impact on selected properties of soil environment of winter wheat. Przem. Chem. 2016, 95, 1591-1594.

53. Jastrzębska, M.; Kostrzewska, M.K.; Makowski, P.; Treder, K.; Jastrzębski, W.P. Granulated phosphorus fertilizer made of ash from biomass combustion and bones with addition of Bacillus megaterium in the field assessment. Part 3. Impact on selected properties of soil environment of winter wheat. Przem. Chem. 2017, 96, 2180-2183.

(C) 2020 by the authors. Licensee MDPI, Basel, Switzerland. This article is an open access article distributed under the terms and conditions of the Creative Commons Attribution (CC BY) license (http://creativecommons.org/licenses/by/4.0/). 